\title{
Mechanism of Tomato Bacterial Wilt Suppression in Soil Amended with Lysine
}

\author{
MARYlene BAgARINAO POSAS ${ }^{1 *}$ and KOKI TOYOTA ${ }^{1}$ \\ ${ }^{1}$ Graduate School of Bio-Applications and Systems Engineering, Tokyo University of Agriculture and Technology, 2-24-16, \\ Naka-cho, Koganei, Tokyo 184-8588, Japan
}

(Received October 13, 2009-Accepted January 22, 2010—Published online February 13, 2010)

\begin{abstract}
The effect of four amino acids, unutilizable by Ralstonia solanacearum, on tomato bacterial wilt (TBW) was tested in three Japanese soils. Results confirmed our previous findings that the addition $\left(2.5 \mathrm{mg} \mathrm{g}^{-1}\right.$ soil $)$ of lysine and serine suppressed TBW, but that of tyrosine and valine did not. The number of the pathogen in non-rhizosphere soil, rhizosphere soil and the rhizoplane was markedly lower in the lysine and serine treatments than in the tyrosine and valine treatments, while the opposite result was obtained for the total bacterial population. Substrate-induced respiration analysis revealed that bacteria became more predominant in the amino acid treatments, especially in lysine. There were no apparent correlations between the microbial activities in soil and the disease index. PCR-DGGE targeting the 16S rRNA gene of the rhizoplane samples from lysine-added Nagoya, Fuchu and Iwate soils revealed 10, 1 and 2 unique bands, respectively, indicating shifts in bacterial community. DGGE patterns in the suppressive treatments belonged to the same cluster while the not suppressive treatments clustered differently. The lower disease incidence of TBW following lysine treatment is likely related to a specific bacterial community in the rhizoplane that developed on the addition of lysine.
\end{abstract}

Key words: microbial activity, induced systemic resistance, survival, denaturing gradient gel electrophoresis (DGGE), canonical correspondence analysis (CCA)

The trend in the control of soilborne diseases inclines more towards the use of certain beneficial bacteria that are indigenous to the plant rhizosphere $(2,12)$. Bacterial wilt caused by Ralstonia solanacearum is a common soilborne plant disease and implicated as one of the major problem associated with the production of various vegetable crops including tomato (13). In the case of tomato bacterial wilt (TBW), biological control of the disease has been attained using a number of antagonistic bacteria including Pseudomonas spp. (24), Bacillus spp. (24, 29), Streptomyces spp. (11), Acinotebacter sp. (19), and avirulent strains or mutants of $R$. solanacearum (3). Majority of these studies generated promising results under controlled laboratory conditions or in the greenhouse but have met with limited success when tested in the field (34). Likewise, the efficacy of wide-scale field applications of biocontrol agents (BCAs) has typically been inconsistent (42), which is closely attributed to poor colonization and/or survival of the introduced BCAs (47). Inconsistency in the effectiveness of BCAs has also been attributed to variability in the physical and chemical properties within the niches occupied by BCAs (30), which influences both colonization of BCAs and expression of the biocontrol mechanisms.

The concentrations of individual amino acids in the rhizosphere of gnotobiotically grown tomato were estimated and found to be inadequate to support the growth of rhizosphere microorganisms up to numbers usually found in the tomato rhizosphere (39). Some studies have shown that organic amendments enhanced the diversity and activity of indigenous microorganisms (22) including the activity of resident

\footnotetext{
* Corresponding author. E-mail: kokit@cc.tuat.ac.jp; Tel: +81-42388-7915; Fax: +81-42-388-7915.
}

BCAs (23). Therefore, the application of amino acids may support and maintain populations of indigenous microorganisms and potential antagonists in the soil including those in the rhizosphere. Abbasi et al. (1) also pointed that organic amendments in soilborne disease management help to maintain high populations of resident beneficial organisms while reducing populations of plant pathogens.

Several approaches to improve the biocontrol efficacy of bacterial antagonists have been made, e.g., the use of nutritional amendments to enhance its colonization and population size (5). The amino acids aspargine and proline, applied separately, increased the population of an antagonistic nonpathogenic bacterial strain on apple fruits, leading to the improved biocontrol of blue mold of apples (18). The suppression of Fusarium wilt of tomato was enhanced when $P$. putida AP-1 was applied together with methionine than AP-1 alone (50). The use of zinc also improved the biological control of Fusarium root and crown rot of tomato by $P$. fluorescens (7). Thereby, the amendment of soil with organic matter or a substrate in the appropriate amount likely improves the rhizosphere competence and the survival of introduced or naturally occurring antagonists in the soil, resulting in effective and sustainable disease control. In relation to the control of TBW, this was demonstrated by the amendment of composted organic manure (17) and the incorporation of air-dried cruciferous residues (31) that probably contributed to the improvement of soil biomass and enhanced activity of specific antagonists. Burkholderia nodosa G5.2rif1 also exhibited a significantly higher and more stable suppression of TBW when applied in combination with sucrose (28). Several studies leading to the biocontrol of soilborne diseases have identified the rhizosphere as a biologically active zone (9) and the successful rhizoplane or root colonization by 
antagonists are the vital factors influencing disease suppression $(25,49)$. Thus, organic amendments might be relevant for the effective colonization of naturally occurring-antagonists for soilborne disease suppression. The application of olive mill waste water also selectively enhanced and sustained bacterial population of r-strategists and induced soil suppressiveness against Rhizoctonia solani (21), as well as created an environment favorable for beneficial microorganisms and suppressive to plant pathogens in hydroponics (20).

Our previous study which screened different organic compounds including amino acids and simple sugars indicated that several compounds displayed suppressiveness against TBW (33). These suppressive compounds included amino acids such as lysine and serine that were unutilizable by $R$. solanacearum. However, valine and tyrosine that were likewise unutilizable by the pathogen were found not suppressive to TBW. Hence, disease suppression was not only related to the utilizability of organic compounds by the pathogen, but there must be other factors governing the suppression of TBW. The effects of organic compound addition on dehydrogenase activity and the pathogen population in non-rhizosphere soil in relation to the incidence of TBW were also assessed. Some of the compounds increased microbial activity and decreased survival of the pathogen which was highly correlated with TBW suppression. However, the mechanisms of TBW suppression, like stimulation of resident microbial antagonist and/or induction of systemic resistance by the suppressive compounds, were not elucidated. Hence, in this study the objective was to conduct a reproducibility test of the suppressive amino acids serine and lysine using three soils from different locations in Japan (Nagoya, Iwate and Fuchu) and to estimate the mechanism of disease suppression especially by the most suppressive compound, lysine. The mechanism of disease suppression was estimated from the effects of the suppressive and conducive amino acids on different microbial aspects, such as microbial number, substrate-induced respiration, activity and community structure. The effect of lysine on induced resistance in tomato plants was also evaluated.

\section{Materials and Methods}

\section{Soil properties}

Soils were collected from the top layer $(0$ to $10 \mathrm{~cm})$ in three locations within Japan. Soil fertilized with chemical fertilizer for more than $14 \mathrm{y}\left[\mathrm{pH}\left(\mathrm{H}_{2} \mathrm{O}\right), 4.3\right.$; total $\mathrm{C}$ and $\mathrm{N}, 8.9$ and $1.1 \mathrm{~g} \mathrm{~kg}^{-1}$; texture, light clay ( $30 \%$ clay, $21 \%$ silt and $50 \%$ sand); type, yellow soil] was taken from the Nagoya University farm (Togo-cho, Aichi prefecture, Japan). The Nagoya soil was reported to be conducive to bacterial wilt disease of tomato (18). Some characteristics of the Nagoya soil were also cited previously $(8,45) . \mathrm{CaCO}_{3}\left(0.32 \mathrm{~g} \mathrm{~kg}^{-1}\right.$ soil) was added to the Nagoya soil to adjust the soil $\mathrm{pH}$ from 4.3 to 6.0. Fuchu soil $\left[\mathrm{pH}\left(\mathrm{H}_{2} \mathrm{O}\right), 6.2\right.$; total $\mathrm{C}$ and $\mathrm{N}, 62.1$ and $5.0 \mathrm{~g} \mathrm{~kg}^{-1}$. texture, clay loam ( $38 \%$ clay, $39 \%$ silt and $22 \%$ sand); type, andosol] was collected from the experimental area of Tokyo University of Agriculture and Technology (TUAT), Fuchu campus. Iwate soil $\left[\mathrm{pH}\left(\mathrm{H}_{2} \mathrm{O}\right), 6.1\right.$; total $\mathrm{C}$ and $\mathrm{N}, 23.8$ and $2.4 \mathrm{~g} \mathrm{~kg}^{-1}$; texture, sandy clay loam (33\% clay, $18 \%$ silt and $49 \%$ sand); type, yellow soil] was collected from a farmer's field in Esashi-city, Iwate prefecture. The soils were manually sieved through a $2-\mathrm{mm}$ mesh sieve and stored at $10^{\circ} \mathrm{C}$ until used.

\section{Disease suppression tests using amino acids}

The bacterial pathogen used was Ralstonia solanacearum (Rs) strain YU1Rif43, a mutant spontaneously resistant to rifampicin (44). RsYU1Rif43 was cultured overnight at $28^{\circ} \mathrm{C}$ in $10^{-1}$ strength nutrient broth (Eiken Chemical, Tokyo, Japan). Subsequently, bacterial cells were washed thrice with sterile distilled water and collected by centrifugation at $13,000 \times \mathrm{g}$ for $5 \mathrm{~min}$. The cell precipitate was resuspended in sterile water to a final density of $10^{8} \mathrm{CFU} \mathrm{mL}^{-1}$ $\left(\mathrm{OD}_{660}=0.3\right)$ and used as an inoculum.

Four amino acids [lysine, serine, tyrosine and valine $(99.5 \%$, Wako Pure Chemicals Industries, Tokyo, Japan)], unutilizable by RsYU1Rif43 and with different levels of disease suppression in our previous study (33), were evaluated for suppressiveness against tomato bacterial wilt disease in biotron experiments using Fuchu, Iwate and Nagoya soils. The organic compounds were added at 2.5 $\mathrm{mg} \mathrm{g}^{-1}$ soil. Each compound was mixed with $100 \mathrm{~g}$ of soil (dry basis) and the mixture was inoculated with the pathogen at $10^{6} \mathrm{CFU}$ $\mathrm{g}^{-1}$ soil and then transferred to an Agripot (Kirin Beer, Tokyo, Japan). Seven tomato (Lycopersicon esculentum Mill. cv. Momotaro) seeds (Takii, Kyoto, Japan) pregerminated for 2 days (28 to $30^{\circ} \mathrm{C}$ ) were transplanted to each pot. Seedlings were thinned from 7 to 6 vigorous plants per pot 3-day after transplanting (DAT). Plants were incubated in a climatron (LPH200, Nippon Medical and Chem. Instruments, Osaka, Japan, conditions: $30^{\circ} \mathrm{C}, 134 \mu \mathrm{mol} \mathrm{m} \mathrm{m}^{-2} \mathrm{~s}^{-1}$ (photon flux) and 12:12h light to dark cycle) for 30 days. Pots were watered regularly to adjust the MWHC to $55 \%$ in Fuchu soil, $50 \%$ in Iwate soil and $45 \%$ in Nagoya soil. Fertilization was done using a diluted Hyponex fertilizer [N (100), P (200), K (100), Mg (10), Mn (0.02) and B (0.1) $\left.\mathrm{mg} \mathrm{L}^{-1} \mathrm{dH}_{2} \mathrm{O}\right]$ (Hyponex Japan, Osaka, Japan) twice a week. Disease infection was noted at 2-day intervals until 30 DAT. The set up was arranged in a completely randomized design and each treatment was replicated thrice with 6 plants per pot.

For the monitoring of the total bacteria and pathogen populations from the rhizosphere soil and rhizoplane, tomato plants (30-day old) from the disease suppression tests above were used. Plants were carefully harvested from the agripots and roots were gently shaken in air to remove all but the tightly adhering soil. Adhering rhizosphere soil ( 2 to $3 \mathrm{~g} \mathrm{pot}^{-1}$ ) was collected by gentle brushing with a fine paintbrush, and then mixed and $1 \mathrm{~g}$ was placed into a test tube with $9 \mathrm{~mL}$ of sterile distilled water. Roots after the brushing were used as rhizoplane samples after cutting into $1-2 \mathrm{~mm}$ pieces. Root macerates were made by adding $0.9 \mathrm{~mL}$ of $0.85 \% \mathrm{NaCl}$ to $0.1 \mathrm{~g}$ of the root pieces and vigorously grinding the mixture with a sterilized mortar and pestle.

The pathogen and total bacterial populations were assessed using $10^{-1}$ strength NA supplemented with $50 \mu \mathrm{g} \mathrm{mL} \mathrm{m}^{-1}$ rifampicin, $50 \mu \mathrm{g}$ $\mathrm{mL}^{-1}$ polymyxin $\mathrm{B}$ and $100 \mu \mathrm{g} \mathrm{mL}^{-1}$ cycloheximide and $10^{-1}$ strength NA with $100 \mu \mathrm{g} \mathrm{mL} \mathrm{mL}^{-1}$ cycloheximide, respectively. The plates were inverted and incubated at $28^{\circ} \mathrm{C}$. Measurements of the density of the pathogen and total bacteria were done in triplicate with 2 plates per replicate. RsYU1Rif43 and total bacteria were recorded 3 and 5 days after spread plating, respectively, and expressed as CFU g $\mathrm{g}^{-1}$ of fresh root.

\section{Population dynamics of culturable bacteria and pathogen}

The numbers of the pathogen and total culturable bacteria were monitored in Nagoya and Fuchu soils added with the different unutilizable amino acids $\left(2.5 \mathrm{mg} \mathrm{g}^{-1}\right.$ soil) with MWHC adjusted to 45 and $55 \%$, respectively and inoculated with the pathogen at $10^{6}$ $\mathrm{CFU} \mathrm{g}{ }^{-1}$ soil. The amended soils $(50 \mathrm{~g})$ were incubated in a $100 \mathrm{~mL}$ glass bottle $\left(28\right.$ to $\left.30^{\circ} \mathrm{C}\right)$ and replicated 3 times. Monitoring of the bacterial pathogen population from non-rhizosphere soil was done by taking about $1 \mathrm{~g}$ of fresh sample and placing it into a test tube with $9 \mathrm{~mL}$ of sterile distilled water. The pathogen and total bacterial populations were assessed as described above at 7, 17 and 30 days after inoculation. 


\section{Dehydrogenase activity and soil respiration test}

The soil samples (Nagoya, Fuchu and Iwate) used in both tests were from the same source used in the monitoring of the population dynamics of culturable bacteria and pathogen. Dehydrogenase activity was measured following the conventional method by Tabatabai (41). Soil (10 g) from each replicate was transferred to a $30 \mathrm{~mL}$ screw cap vial with a butyl stopper and the $\mathrm{CO}_{2}(0.5 \mathrm{~mL})$ concentration in the headspace was quantified at 7,17 and 30 days after amino acid addition by gas chromatography using a Shimadzu GC-8A with a thermal conductivity detector (Shimadzu, Kyoto, Japan) equipped with a stainless steel column packed with Porapak-Q (80/100 mesh, $3 \mathrm{~mm} \varnothing$ and $2 \mathrm{~m}$ length). The GC used helium as a carrier gas, a thermal detector temperature set at $80^{\circ} \mathrm{C}$ and column temperature adjusted to $60^{\circ} \mathrm{C}$

\section{Induced systemic resistance test}

Leaf-cutting method. Six pre-germinated "Momotaro" seedlings were transplanted individually into a biodegradable fertil pot (8 cm Ø) (Takii Seed, Kyoto, Japan) with Fuchu soil (160 g) amended with lysine and tyrosine $\left(1.0 \mathrm{mg} \mathrm{g}^{-1}\right.$ soil). The seedlings were allowed to grow in the amended soil for a month in a Biotron in order to determine if the amino acids induce systemic resistance in tomato plants. One month after transplanting, plants were subsequently inoculated with 24-h old growth culture of RsYU1Rif43 in NB, which was diluted 200 times with distilled water. Inoculation was carried out by cutting halfway one terminal leaf per plant with the use of sterilized scissors previously dipped in the pathogen suspension $\left(2.5 \times 10^{6}\right.$ cells $\left.\mathrm{mL}^{-1}\right)$ for $30 \mathrm{~s}$. Tomato plants treated with validamycin A (VMA) (Sumitomo Chemical, Tokyo, Japan), proven to induce systemic acquired resistance (SAR) in tomato (16) were used as a positive control. The soil used in this positive control treatment was not amended with amino acid. VMA $\left(100 \mu \mathrm{g} \mathrm{mL}^{-1}\right)$ was applied as described by Ishikawa et al. (16) as a foliar spray onto the foliage of tomato plants, one week before inoculation with RsYU1Rif43. Control plants provided only with distilled water served as a negative control. Each treatment was replicated 3 times with 5 plants per replication.

Transplanting method. The conditions for tomato pre-cultivation and amino acid application were similar to those adopted in the leaf-cut technique but instead seedlings were grown in a smaller fertil pot $(3 \mathrm{~cm} \varnothing)$ with $40 \mathrm{~g}$ of soil. Challenge inoculation with the pathogen was done by transplanting the entire pot together with the plant (30-day old) into a larger $10 \mathrm{~cm} \varnothing$ polyethylene pot (Takii Seed, Kyoto, Japan). Soil contained in the larger fertil (200 g) pot was mixed with RsYU1Rif43 at $1 \times 10^{6} \mathrm{CFU} \mathrm{g}^{-1}$ soil just before transplanting and not amended with amino acids. Each treatment had 3 replicates with 6 plants per pot. Then, the plants were incubated in a biotron and disease severity was recorded since every 2 day after the challenge inoculation until 30 DAT by determining the percentage of plants wilted. Test plants showing typical bacterial wilt symptoms were scored as diseased.

\section{Substrate-induced respiration experiment}

A selective substrate-induced respiration (SIR) method was used to estimate bacterial and fungal biomass as reported previously (47). The Nagoya or Fuchu soil (900 g) was divided into three samples (300 g each) and each subsample (100 g each) was added without or with lysine or tyrosine at $2.5 \mathrm{mg} \mathrm{g}^{-1}$ soil in triplicate and placed in a $200 \mathrm{~mL}$ screw cap plastic bottle. The soil-amino acid mixtures were acclimatized for 1 week at $28^{\circ} \mathrm{C}$ with a moisture content equivalent to $55 \% \mathrm{MWHC}$. Then, $10 \mathrm{~g}$ of soil from each subsample was placed into a $30 \mathrm{~mL}$ screw glass vial in triplicate and applied with either rifampicin/kanamycin sulfate $\left(2 \mathrm{mg} \mathrm{g}^{-1}\right.$ dry soil) or cycloheximide ( $2 \mathrm{mg} \mathrm{g}^{-1}$ dry soil) for the selective inhibition of bacteria and fungi, respectively, together with glucose at $10 \mathrm{mg} \mathrm{g}^{-1}$ dry soil. The $\mathrm{CO}_{2}(0.5 \mathrm{~mL})$ concentration in the headspace was quantified by gas chromatography as above. The $\mathrm{CO}_{2}$ production was measured at 0 to $10 \mathrm{~h}$ after the addition of the antibiotics and glucose.
Assessment of bacterial and fungal communities by DNA profiles

The bacterial and fungal community structures in the tomato rhizosphere soil and root were determined by profiling genes encoding eubacterial 16S rRNA and 18S rRNA, respectively, via PCR and subsequent DGGE analysis. DNA was extracted from the rhizosphere soil $(0.5 \mathrm{~g})$ as described by Sato et al. (36). DNA extraction from $0.1 \mathrm{~g}$ of chopped tomato root was carried out as described by Shrestha et al. (38). The DNA pellet was washed with $70 \%$ ethanol, vacuum dried and resuspended in $50 \mu \mathrm{L}$ of TE buffer. The DNA samples from the rhizosphere soil and root were diluted, and stored at $-80^{\circ} \mathrm{C}$, and used as a template for PCR amplification. For bacteria, PCR amplicons were generated by using the primer pair F968GC (5'-CGC CCG GGG CGC GCC CCG GGC GGG GCG GGG GCA CGG GGG GAA CGC GAA GAA CCT TAC-3') and 1378r (5'-CGG TGT GTA CAA GGC CCG GGA ACG-3'). Each $25 \mu \mathrm{L}$ PCR reaction contained $1 \mu \mathrm{L}$ of DNA plus $24 \mu \mathrm{L}$ of amplification mixture $\left(250 \mu \mathrm{M}\right.$ dNTP mix, $1.5 \mathrm{mM} \mathrm{MgCl}_{2}, 1.8 \mu \mathrm{M}$ F968GC, $0.3 \mu \mathrm{M} 1378 \mathrm{r}$ and 5 units $\mu \mathrm{L}^{-1}$ Taq polymerase in $1 \times$ buffer) (Ex Taq, Takara Bio, Ohtsu, Japan) and $0.4 \mathrm{mg} \mathrm{mL} \mathrm{mL}^{-1}$ BSA. The thermal profile for amplification was $94^{\circ} \mathrm{C}$ for $3 \mathrm{~min} ; 30$ cycles at $94^{\circ} \mathrm{C}$ for $1 \mathrm{~min}, 55^{\circ} \mathrm{C}$ for $1 \mathrm{~min}$, and $72^{\circ} \mathrm{C}$ for $1 \mathrm{~min} 30 \mathrm{~s}$, and $72^{\circ} \mathrm{C}$ for $7 \mathrm{~min}$. PCR products ( 15 to $\left.20 \mu \mathrm{L}\right)$ were separated in a $6 \%$ acrylamide gel with a linear denaturing gradient of $40-70 \%$ in a Bio-Rad D-Code Universal Detection System (Bio-Rad, Hercules, CA, USA) for 16 to $17 \mathrm{~h}$ at $80 \mathrm{v}$ and $60^{\circ} \mathrm{C}$. For fungi, a partial sequence of the 18S rRNA gene was amplified by nested PCR as described by Oros-Sichler et al. (32). But, the second PCR was done using the primer pair NS1 and the fungus-specific primer GCfung (4, 26). Amplification was carried out with GoTaq Green Master Mix (Promega, Madison, WI, USA.) with a $0.2 \mu \mathrm{M}$ concentration of each primer, $0.4 \mathrm{mg} \mathrm{mL}^{-1} \mathrm{BSA}$ and $1 \mu \mathrm{L}$ of the diluted primary PCR product $(1: 20)$ as template. The product from the amplification with NS1 and GCfung was analyzed with the DCode mutation detection system. Samples (10 to $15 \mu \mathrm{l})$ were loaded on $7 \%(\mathrm{w} / \mathrm{v})$ polyacrylamide gels with a denaturing gradient from 20 to $45 \%$ (100\% denaturant, $7 \mathrm{M}$ urea and 40\% formamide). The gels were run in $1 \times \mathrm{TAE}$ at $50 \mathrm{~V}$ and $60^{\circ} \mathrm{C}$ for $18 \mathrm{~h}$. DGGE gels were stained with a 1:10000 SYBR Green I nucleic acid solution, photographed on a UV Transilluminator and visualized with Doc-ItLS Image Analysis Software (UVP, Upland, CA, USA).

\section{Band excision and sequencing}

For bacteria, bands of interest were excised from the DGGE gel and kept overnight at $4^{\circ} \mathrm{C}$ in $100 \mu \mathrm{L}$ of TE buffer. The eluted fraction $(1 \mu \mathrm{L})$ was used as a template for PCR as described above with the reverse primer 1378r-seq (5'-CAG GAA ACA GCT ATG ACC CGG TGT GTA CAA GGC CCG GGA ACG-3'). Products were analyzed by DGGE with the original total-community samples to verify equality of fragments mobility and position. Bands were repeatedly re-amplified, electrophoresed and excised until a single target band was confirmed in DGGE. PCR samples of the confirmed band were purified with Suprec ${ }^{\mathrm{TM}}$ PCR (Takara Bio) and sent for sequencing to Takara Bio Inc. The resulting $16 \mathrm{~S}$ rRNA sequence was examined using DDBJ with the BLAST homology search system (http://blast.ddbj.nig.ac.jp).

\section{Analysis of DGGE fingerprints}

A cluster analysis was done using BioNumerics ver. 4.5 software (Applied Maths BVBA, Sint-Martens-Latem, Belgium) with the Pearson product-moment correlation as similarity coefficient test and the Ward method of analysis to generate the dendrogram. To address which factor has a large influence on TBW suppression, different experimental parameters (factors of interest); disease index, dehydrogenase activity, soil respiration and the numbers of pathogen and total bacteria and their interaction with the rhizoplane DGGE profiles from amino acid amended Nagoya and Fuchu soil were analyzed by ordination technique. The statistical analysis of DGGE profiles based on the relative intensity of each band versus the experimental variables was performed using canonical corre- 
spondence analysis with $\mathrm{R}$ version 2.8.1 software (The R Foundation for Statistical Computing, Vienna, Austria). The conditions and advantages of canonical correspondence analysis were discussed elsewhere $(35,43)$. In order to determine statistical significance, the different parameters were subjected to multi regression analysis (Excel Statistics 2006 for Windows: SSRI, Tokyo, Japan).

\section{Greenhouse trial}

The suppressive effect of lysine against TBW was verified under greenhouse conditions at the Center for Innovation and Intellectual Property, TUAT, Koganei campus from May 1 to September 5, 2008. In this trial, lysine (98.5\% purity) which is used as an additive for livestock feed formulations was used as an alternative economical source of the amino acid. Seedlings were prepared at the greenhouse of BASE, TUAT from March 29 to April 30, 2008. Three pre-germinated (2-day) "Momotaro" seeds were transplanted to 160 $\mathrm{g}$ of Fuchu soil previously applied with lysine in a biodegradable pot $(8 \mathrm{~cm} \varnothing)$. Lysine was applied separately at 1.0 and $2.5 \mathrm{mg} \mathrm{g}^{-1}$ soil. Seedlings (3) were thinned at 3 DAT (April 3, 2008) to 1 plant per pot. After one month (May 1, 2008), lysine was added at the same rates to $8 \mathrm{~kg}$ of Fuchu soil inside a 1/2000a Wagner's pot (Fujiwara Scientific, Tokyo, Japan) and every 2-week thereafter. Complete fertilizer was applied at $100-100-100 \mathrm{~kg} / \mathrm{ha}$. The soil mixture was inoculated with RsYU1Rif43 $\left(1 \times 10^{6} \mathrm{CFU} \mathrm{g}{ }^{-1}\right.$ soil) and mixed thoroughly. Two biodegradable pots with 1 seedling each (30-day old) were transplanted entirely to the soil mixture. After 1 month (June 1, 2008), one tomato plant was carefully uprooted and the culturable populations of the pathogen and total bacteria were enumerated from the roots by dilution plate method. Disease infection was recorded using the disease index described above. The quality of harvested matured tomato fruits was measured following the method by Nion and Toyota (28). The set up was laid out in a completely randomized manner with each treatment consisting of six pots with 1 plant per pot.

\section{Statistical analysis}

Data were subjected to analysis of variance and significant differences between treatments were estimated with the protected Fisher's LSD and Tukey tests using Excel Statistics, 2006 for Windows.

\section{Accession numbers of nucleotide sequences}

The nucleotide sequences obtained in this study were deposited in the DDBJ database with the following accession numbers: AB550132 to AB550141.

\section{Results}

\section{TBW suppression tests with amino acids}

Comparison of the effectiveness of these unutilizable amino acids at a rate of $2.5 \mathrm{mg} \mathrm{g}^{-1}$ dry soil showed that lysine significantly suppressed TBW caused by RsYU1Rif43, closely followed by serine (Fig. 1). This apparent low disease incidence of tomato plants grown in the lysine treatment was reproducible in two trials for each soil and consistent irrespective of the three soils tested (Nagoya, Fuchu and Iwate soils). The addition of tyrosine and valine, although unutilizable by the pathogen, did not suppress TBW in most cases, with about 95 to $100 \%$ of tomato plants wilted at 30 DAT (Fig. 1). Treatment with valine caused a slight reduction of TBW in Fuchu soil but still statistically comparable to the con+ (inoculated with the pathogen alone).

\section{Population dynamics of culturable bacteria and the pathogen}

In Nagoya soil, the pathogen population at 30-day after

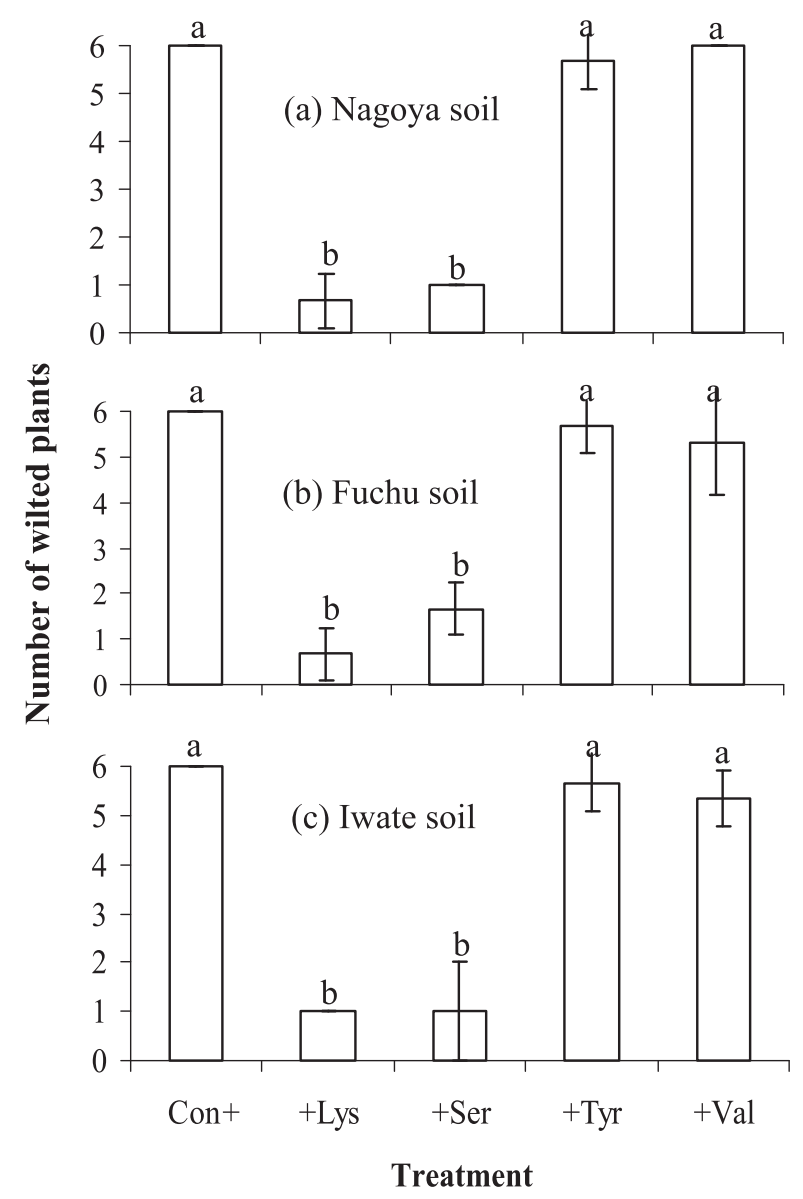

Fig. 1. Effect of the soil addition of unutilizable amino acids at 2.5 $\mathrm{mg} \mathrm{g}^{-1}$ soil on the disease incidence of TBW in (a) Nagoya, (b) Fuchu and (c) Iwate soil at 30 days after inoculation of the pathogen. Data are means of 3 replicated pots with 6 plants per pot from 2 trials. Bars with the same letter are not significantly different according to Fisher's protected LSD test $(P<0.001)$. Con+, with RsYU1Rif43 (Rs) alone; +Lys, lysine+Rs; +Ser, serine+Rs; +Tyr, tyrosine+Rs; +Val, valine+Rs.

addition was more than 20 times lower in the lysine and serine treatments than the con + , while that in the tyrosine and valine treatments were comparable to the con+ (Fig. 2a). In contrast, total bacterial counts were significantly higher in the lysine and serine treatments followed by tyrosine, valine and lastly the con+ (Fig. 2b). Similar results were also obtained in Fuchu soil (Fig. 2c, 2d).

In the rhizosphere soil, lysine and serine treatments had significantly $(P<0.001)$ the lowest population of the pathogen followed by tyrosine, valine and con+ at 30-day after amino acid addition in Nagoya soil (Table 1). Total bacterial numbers were also significantly higher in serine and lysine treatments than in tyrosine, valine, and con+. Similar trends were noted in the populations of the pathogen and total bacteria from the rhizosphere in Fuchu and Iwate soils amended with the different amino acids (Table 1).

In the rhizoplane samples, lysine and serine at 30-day after amino acid addition in Nagoya soil had significantly $(P<0.001)$ the lowest populations of the pathogen followed by con+, valine and tyrosine (Table 1$)$. Total bacteria were also significantly highest in serine and lysine than in tyrosine, valine and con+. A similar trend was observed in 


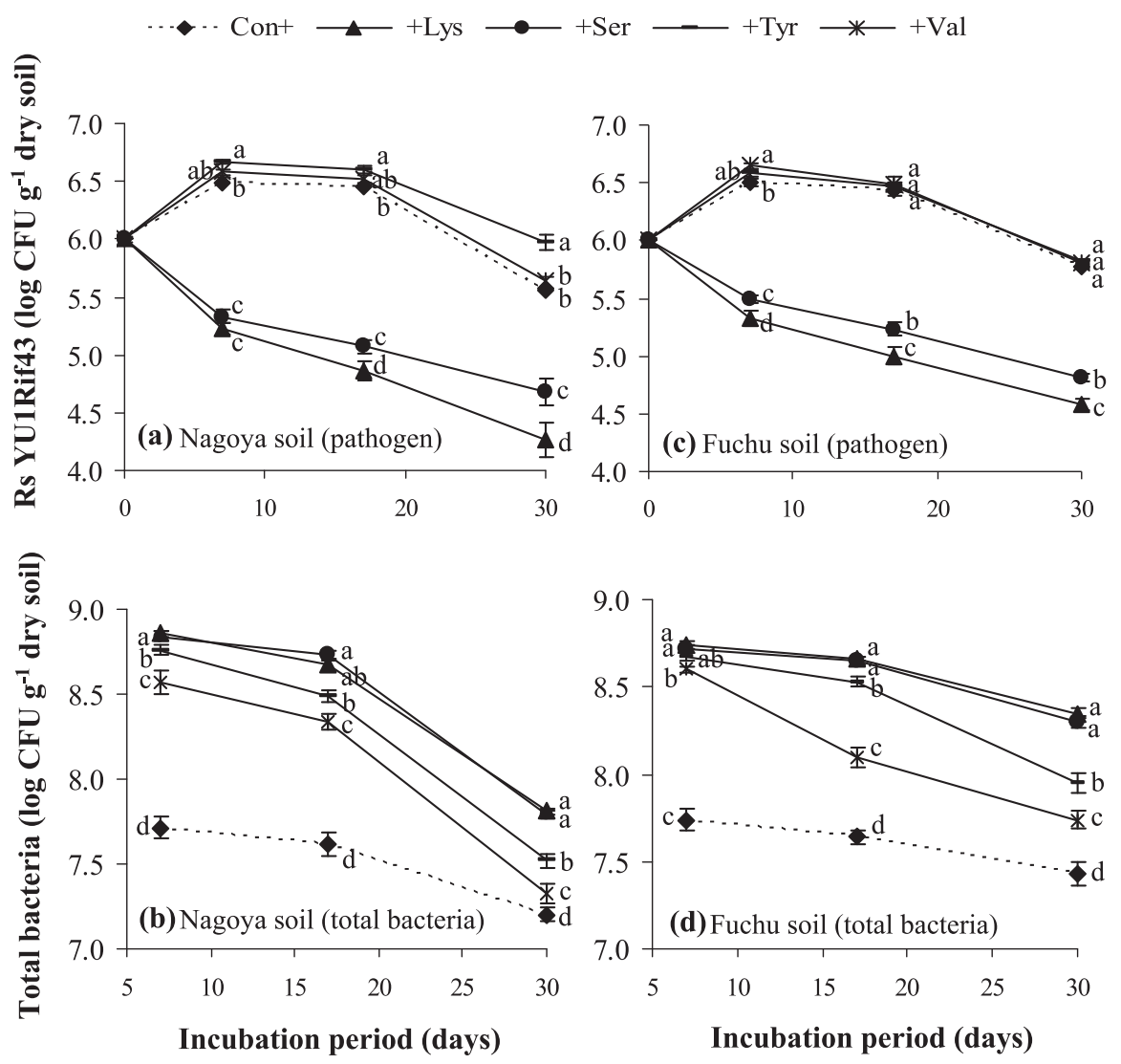

Fig. 2. Effect of the soil addition of amino acids $\left(2.5 \mathrm{mg} \mathrm{g}^{-1}\right.$ soil) on the (a) pathogen and (b) total bacteria in Nagoya soil and (c) pathogen and (d) total bacteria in Fuchu soil at 7, 17 and 30 days after mixing.

Table 1. Effect of the soil addition of amino acids at $2.5 \mathrm{mg} \mathrm{g}^{-1}$ soil on the pathogen and total bacteria in the rhizosphere soil and rhizoplane of tomato in Nagoya, Fuchu and Iwate soil at 30 days after inoculation of the pathogen

\begin{tabular}{|c|c|c|c|c|c|c|}
\hline \multirow{2}{*}{ Treatment } & \multicolumn{2}{|c|}{ Nagoya } & \multicolumn{2}{|c|}{ Fuchu } & \multicolumn{2}{|c|}{ Iwate } \\
\hline & YU1Rif43 & Total bacteria & YU1Rif43 & Total bacteria & YU1Rif43 & Total bacteria \\
\hline \multicolumn{7}{|c|}{ a) Rhizosphere soil population ( $\log \mathrm{CFU} \mathrm{g}{ }^{-1}$ dry soil)* } \\
\hline Control+ & $5.51 \pm 0.05 \mathrm{a}$ & $7.17 \pm 0.19 \mathrm{c}$ & $5.54 \pm 0.03 \mathrm{a}$ & $7.29 \pm 0.01 \mathrm{c}$ & $5.54 \pm 0.04 \mathrm{a}$ & $7.20 \pm 0.02 \mathrm{c}$ \\
\hline +Lysine & $5.37 \pm 0.01 \mathrm{c}$ & $8.33 \pm 0.06 \mathrm{~b}$ & $5.25 \pm 0.01 \mathrm{c}$ & $8.60 \pm 0.04 \mathrm{a}$ & $5.12 \pm 0.03 \mathrm{c}$ & $8.58 \pm 0.02 \mathrm{a}$ \\
\hline+ Serine & $5.34 \pm 0.03 \mathrm{c}$ & $8.42 \pm 0.03 \mathrm{a}$ & $5.32 \pm 0.02 \mathrm{~b}$ & $8.61 \pm 0.01 \mathrm{a}$ & $5.23 \pm 0.07 \mathrm{~b}$ & $8.60 \pm 0.01 \mathrm{a}$ \\
\hline +Tyrosine & $5.43 \pm 0.06 \mathrm{~b}$ & $7.24 \pm 0.02 \mathrm{~b}$ & $5.51 \pm 0.02 \mathrm{a}$ & $7.39 \pm 0.03 \mathrm{~b}$ & $5.50 \pm 0.01 \mathrm{a}$ & $7.38 \pm 0.03 \mathrm{~b}$ \\
\hline +Valine & $5.49 \pm 0.01 \mathrm{a}$ & $7.27 \pm 0.03 \mathrm{~b}$ & $5.52 \pm 0.02 \mathrm{a}$ & $7.37 \pm 0.03 \mathrm{~b}$ & $5.54 \pm 0.02 \mathrm{a}$ & $7.35 \pm 0.04 \mathrm{~b}$ \\
\hline \multicolumn{7}{|c|}{ a) Rhizoplane population (log CFU g ${ }^{-1}$ fresh root)* } \\
\hline Control+ & $7.20 \pm 0.03 \mathrm{~b}$ & $7.35 \pm 0.02 \mathrm{~b}$ & $7.30 \pm 0.05 \mathrm{a}$ & $7.45 \pm 0.06 \mathrm{~b}$ & $7.26 \pm 0.03 \mathrm{a}$ & $7.35 \pm 0.06 \mathrm{c}$ \\
\hline +Lysine & $6.23 \pm 0.01 \mathrm{c}$ & $8.58 \pm 0.02 \mathrm{a}$ & $6.51 \pm 0.03 \mathrm{c}$ & $8.77 \pm 0.01 \mathrm{a}$ & $6.21 \pm 0.05 \mathrm{~b}$ & $8.45 \pm 0.02 \mathrm{a}$ \\
\hline+ Serine & $6.25 \pm 0.02 \mathrm{c}$ & $8.60 \pm 0.03 \mathrm{a}$ & $6.44 \pm 0.04 \mathrm{c}$ & $8.79 \pm 0.01 \mathrm{a}$ & $6.21 \pm 0.02 \mathrm{~b}$ & $8.35 \pm 0.02 \mathrm{~b}$ \\
\hline +Tyrosine & $7.33 \pm 0.01 \mathrm{a}$ & $7.38 \pm 0.02 \mathrm{~b}$ & $7.31 \pm 0.04 \mathrm{a}$ & $7.35 \pm 0.04 \mathrm{c}$ & $7.29 \pm 0.04 \mathrm{a}$ & $7.32 \pm 0.05 \mathrm{c}$ \\
\hline +Valine & $7.25 \pm 0.03 \mathrm{~b}$ & $7.35 \pm 0.04 \mathrm{~b}$ & $7.14 \pm 0.10 \mathrm{~b}$ & $7.32 \pm 0.03 \mathrm{c}$ & $7.28 \pm 0.06 \mathrm{a}$ & $7.31 \pm 0.03 \mathrm{c}$ \\
\hline
\end{tabular}

* Rhizosphere soil and rhizoplane samples were taken from its corresponding experiment in Fig. 1. Data are means of 3 replicates from two trials. Values in each column with the same letter are not significantly different according to protected Fisher's LSD test $(P<0.001)$.

the populations of the pathogen and total bacteria in Fuchu and Iwate soils added with the different amino acids (Table $1)$.

\section{Soil respiration and dehydrogenase activity of amino acid amended soils}

All the amino acids $\left(2.5 \mathrm{mg} \mathrm{g}^{-1}\right.$ dry soil) enhanced $\mathrm{CO}_{2}$ production at 7-day after addition (Fig. 3). In Nagoya soil, soil respiration was significantly $(P<0.001)$ higher in serine followed by tyrosine and lysine, and valine with 76, 42, 35 and $19 \%$ increase than con+ at 7 -day (Fig. 3a). Likewise, in Fuchu soil, respiration was also significantly $(P<0.001)$ highest in serine and tyrosine followed by lysine and valine with $10.0,9.6,8.0$ and 6.7 times increased relative to con+, respectively at the same period of incubation (7-day) (Fig. 3b). 
The different amino acid (2.5 $\mathrm{mg} \mathrm{g}^{-1}$ dry soil) additions showed statistically higher dehydrogenase activity than the con+ in Nagoya and Fuchu soils (Fig. 4). In Nagoya soil at 30-day, the activity of dehydrogenase was significantly high-

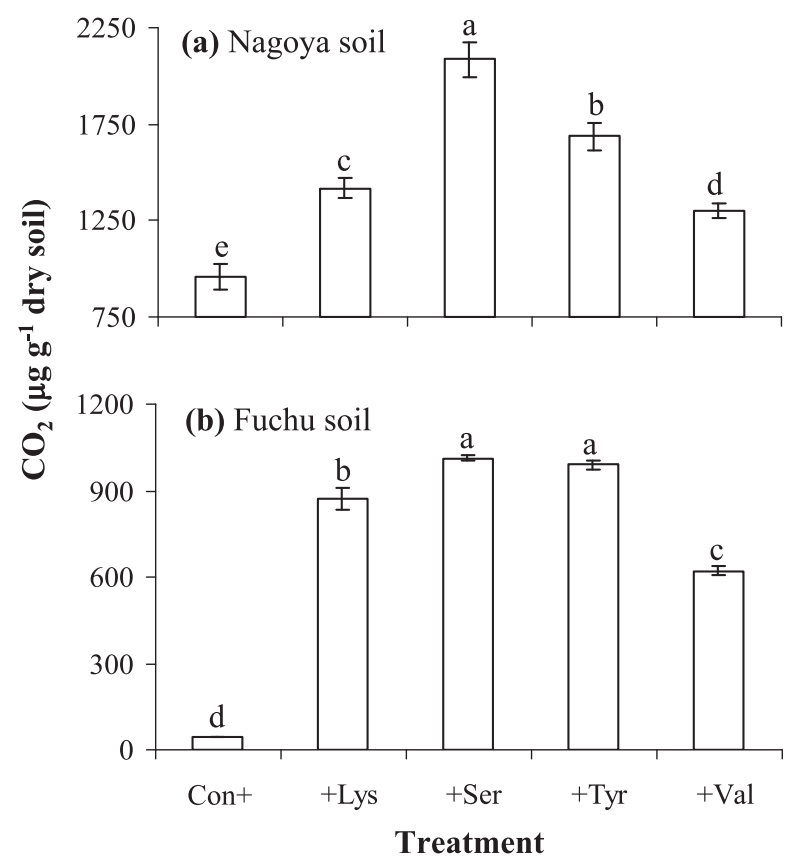

Fig. 3. Soil respiration of (a) Nagoya and (b) Fuchu soil added with the different amino acids $\left(2.5 \mathrm{mg} \mathrm{g}^{-1}\right.$ soil) at 7-day after mixing.

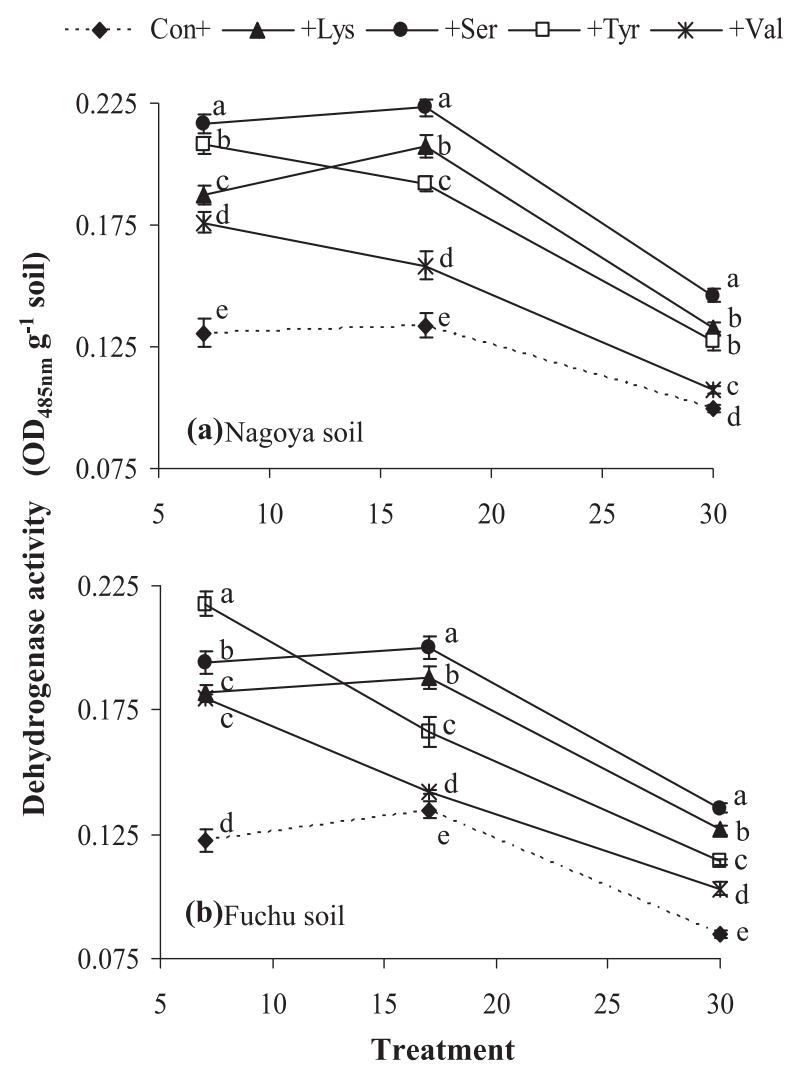

Fig. 4. Dehydrogenase activity of (a) Nagoya and (b) Fuchu soil added with the different amino acids $\left(2.5 \mathrm{mg} \mathrm{g}^{-1}\right.$ soil $)$ at 7,17 and 30 days after mixing. est in serine followed by lysine which was comparable to tyrosine, valine and lastly con+ (Fig. 4a). In Fuchu soil, dehydrogenase activity was also significantly highest in serine followed by lysine and tyrosine, valine and the least in con + at the same period of incubation (Fig. 4b).

\section{Substrate-induced respiration experiment}

Substrate-induced respiration test showed that Nagoya $(66 \%)$ and Fuchu $(72 \%)$ soil was originally dominated by fungi rather than bacteria (Table 2). Subsequent addition of the amino acids increased bacterial respiration. In Nagoya soil, the percentage of bacteria was significantly $(P<0.001)$ highest in lysine $(81 \%)$ followed by serine $(77 \%)$, tyrosine $(71 \%)$, valine $(64 \%)$ and con- (treated with water alone) (34\%) (Table 2). Fungal respiration accounted only for 19 , 23, 29 and $36 \%$ in lysine, serine, tyrosine and valine amended soil, respectively. In Fuchu soil, substrate-induced respiration also showed that bacteria became significantly $(P<0.001)$ predominant in the soil with lysine $(75 \%)$ than in tyrosine (68\%) and con- (28\%) (Table 2).

\section{Induced systemic resistance test}

Transplanting method. Test plants became completely infected at 30 DAT when the seedlings were grown in pots containing Fuchu soil added with lysine for one month and then transplanted to soil without any amino acid addition but inoculated with the pathogen (data not shown).

Leaf-cut method. The same result was also obtained in the leaf-cut method in which tomato was planted in soil added with lysine for one month prior to subsequent challenge inoculation of the pathogen. Disease development was rapid with $100 \%$ of the test plants in the lysine treatment succumbed to TBW even at 14 days after the inoculation of the pathogen, while only $30 \%$ of plants treated with validamycin A displayed wilt infection.

\section{PCR-DGGE $16 S$ and $18 S$ rRNA gene analysis of tomato root and cluster analysis}

The different amino acid additions generated considerable changes in bacterial community composition of harvested tomato roots (Fig. 5). In Nagoya soil, the highest number

Table 2. Estimation of dominant microbial community in (a) Nagoya and (b) Fuchu soil one week after the amendment of different amino acids $\left(2.5 \mathrm{mg} \mathrm{g}^{-1}\right.$ soil) compared to the controlwithout amino acid addition by substrate induced respiration test

\begin{tabular}{ccc}
\hline Treatment & Bacteria (\%) & Fungi (\%) \\
\hline a) Nagoya soil & & \\
Control- & $34 \mathrm{e}$ & $66 \mathrm{a}$ \\
+Lysine & $81 \mathrm{a}$ & $19 \mathrm{e}$ \\
+Serine & $77 \mathrm{~b}$ & $23 \mathrm{~d}$ \\
+Tyrosine & $71 \mathrm{c}$ & $29 \mathrm{c}$ \\
+Valine & $64 \mathrm{~d}$ & $36 \mathrm{~b}$ \\
b) Fuchu soil & & \\
Control- & $28 \mathrm{c}$ & $72 \mathrm{a}$ \\
+Lysine & $75 \mathrm{a}$ & $25 \mathrm{c}$ \\
+Serine & $68 \mathrm{~b}$ & $32 \mathrm{~b}$ \\
\hline
\end{tabular}

Values in each column with different letters are significantly different according to Tukey test $(P<0.001)$. 


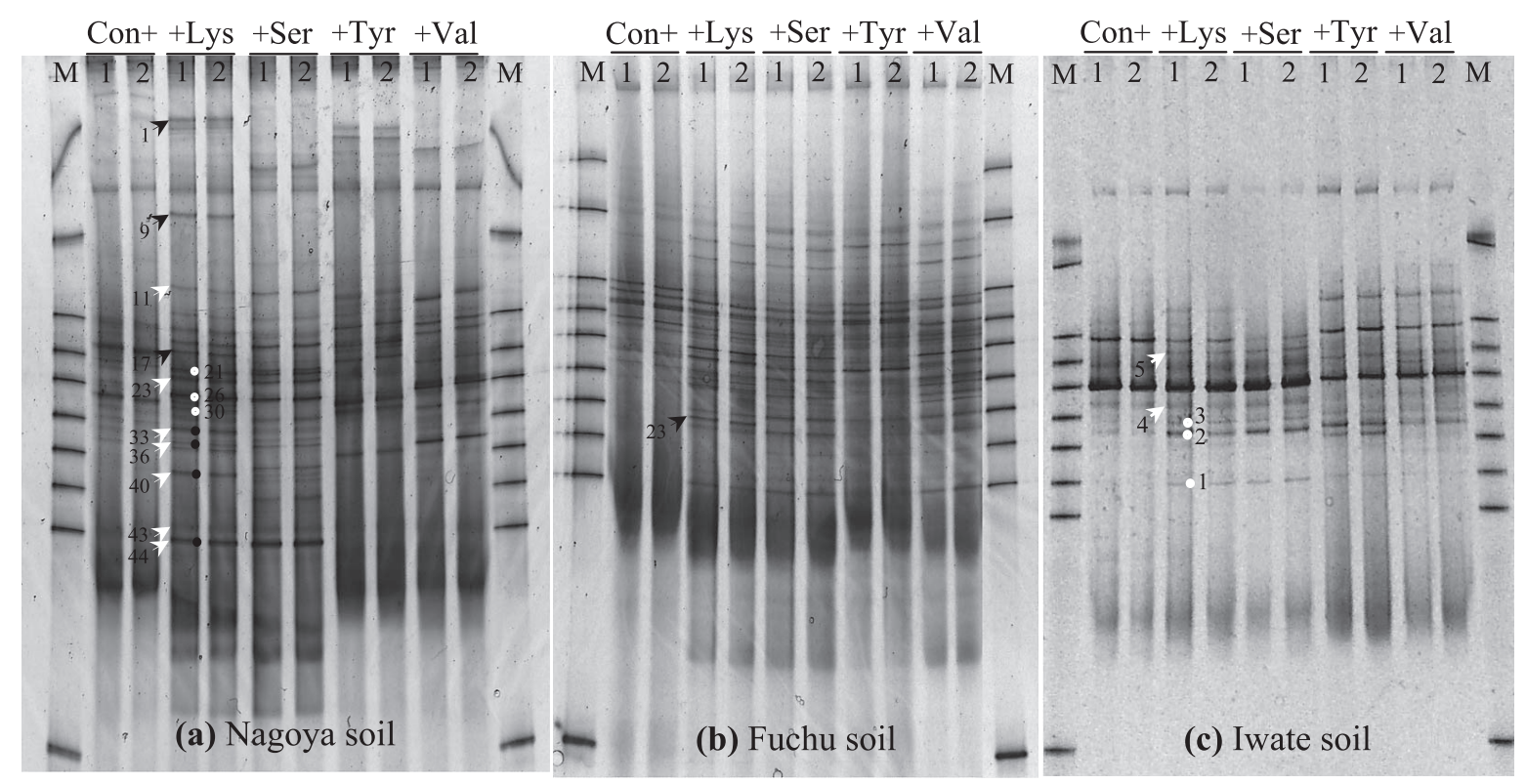

Fig. 5. DGGE analysis of eubacterial $16 \mathrm{~S}$ rRNA gene retrieved from tomato roots in amino acid (2.5 $\left.\mathrm{mg} \mathrm{g}^{-1}\right)$ added (a) Nagoya (b) Fuchu and (c) Iwate soil at 30 DAT. M, marker. Bands with white arrows are present in + Lys and + Ser and not found in + Tyr and + Val. Bands with black arrow are unique only in + Lys. Bands with small circles designate bands recovered and sequenced.

(around 22) of bands was detected in the lysine treatment followed by serine with 21 bands. There were 15 bands in the con+ and valine treatments and 16 bands in the tyrosine treatment (Fig. 5a). Ten unique bands (with arrow) were observed in the lysine treatment, which were absent in the tyrosine and valine treatments (Fig. 5a). Out of these 10 bands, 3 were unique to the lysine treatment, while the other 7 bands (with white arrow) were common to the lysine and serine treatments (Fig. 5a).

In Fuchu soil, the highest number (23 bands) of bands was counted in the lysine treatment, closely followed by the serine treatment ( 22 bands), while there were around 18 and 19 bands in the valine and tyrosine treatments, respectively (Fig. 5b). The lowest number (13 bands) was observed in the cont + . There was one unique band (no. 23) in the lysine treatment.

In Iwate soil, the highest number (10 bands) of bands was also observed in the lysine treatment, followed by the serine ( 9 bands) and tyrosine ( 9 bands) and valine ( 8 bands) treatments (Fig. 5c). The cont+ (6 bands) had the lowest number of bands. Two bands (with white arrow) were common to the lysine and serine treatments but absent in tyrosine and valine treatments.

DGGE patterns in the suppressive amino acid treatments (lysine and serine) belonged to the same cluster, as did the not suppressive treatments (con+, tyrosine and valine) in Nagoya soil (Fig. 6a). A similar tendency was observed in Fuchu soil (Fig. 6b) and Iwate soils (Fig. 6c).

The 16S rRNA sequence analyses of DGGE bands in Nagoya soil showed that bands no. 33, 36 and 40 observed only in the lysine and serine treatments, showed high similarity to Streptomyces sp. 172633c (98\%), Streptomyces recifensis strain ST100 (98\%) and Rhodanobacter lindaniclasticus (99\%), respectively (Table 3). Band no. 44 present only in the lysine and serine treatments, was closer to Paenibacillus abekawaensis with $90 \%$ similarity. The other three
Pearson correlation $(0.0 \%-100.0 \%)$
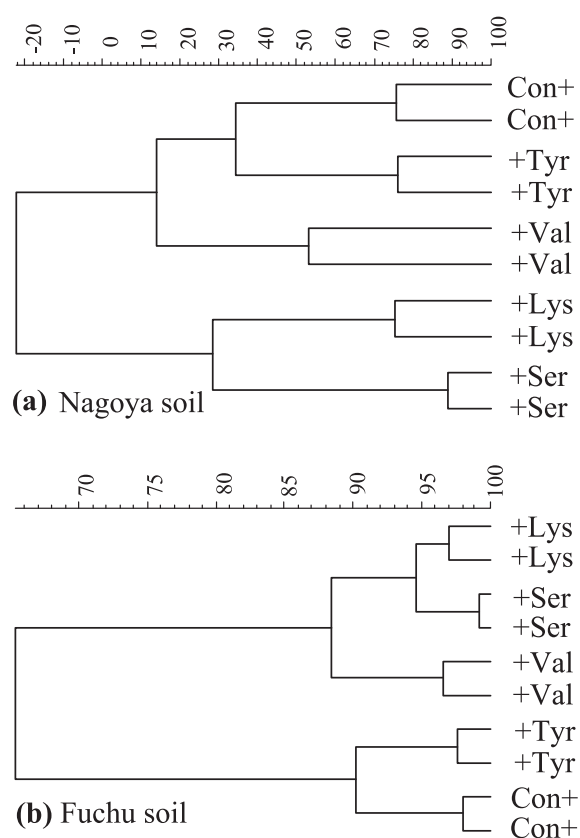

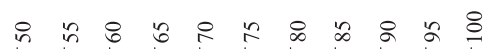

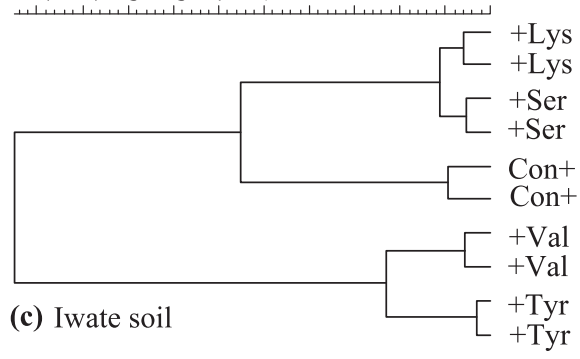

Fig. 6. Cluster analysis of DGGE patterns of rhizoplane bacterial communities from different amino acid treatments in (a) Nagoya, (b) Fuchu and (c) Iwate soil. 
Table 3. Primary BLAST matches to known species of sequences obtained from excised DGGE bands from lysine treatment in Nagoya and Iwate soil

\begin{tabular}{|c|c|c|c|c|}
\hline Band no. & Accession no. & Closest phylotype or species (accession no.) & Similarity $(\%)$ & Taxonomic group \\
\hline \multicolumn{5}{|l|}{ a) Nagoya soil ${ }^{a}$} \\
\hline 21 & AB550138 & Streptomyces sakainensis (AB184762) & 99 & Actinobacteria \\
\hline 30 & AB550136 & Luteolibacter pohnpeiensis (AB331895) & 94 & Verrucomicrobia \\
\hline 33 & AB550135 & Rhodanobacter lindaniclasticus (AB245366) & 99 & Gammaproteobacteria \\
\hline 36 & AB550134 & Streptomyces recifensis strain ST100 (EU216596) & 98 & Actinobacteria \\
\hline 40 & AB550133 & Streptomyces sp. 172633c (EF550511) & 98 & Actinobacteria \\
\hline 44 & AB550132 & Paenibacillus abekawaensis (AB119649) & 90 & Firmicutes \\
\hline \multicolumn{5}{|l|}{ b) Iwate soil } \\
\hline 1 & AB550139 & Streptomyces beijiangensis clone B9 (EU196534) & 100 & Actinobacteria \\
\hline 2 & AB550140 & Fulvimonas sp. NML 060897 (EF589680) & 99 & Gammaproteobacteria \\
\hline 3 & AB550141 & Xanthomonadaceae bacterium WH2 (EU780170) & 85 & Gammaproteobacteria \\
\hline
\end{tabular}

${ }^{a}$ In Nagoya soil band nos. 33, 36, 40 and 44 were unique bands common in +Lys and +Ser treatments (absent in +Tyr and +Val) with successful sequencing. The 4 bands were negatively correlated to the disease index in the CCA plot.

bands, no. 21, 26 and 30 commonly observed in all the amino acid treatments corresponded to Luteolibacter pohnpeiensis (94\%), Arthrobacter nicotovorans strain X9-33 (99\%) and Streptomyces sakainensis (99\%), respectively (Table 2). The three unique bands, no. 1, 9 and 17 only observed in the lysine treatment (Fig. 5a) were not successfully sequenced. In Iwate soil, bands no. 1, 2 and 3 commonly found in all the treatments (Fig. 5c) showed nearest similarity to Streptomyces beijiangensis (100\%), Fulvimonas sp. (99\%) and Xanthomonadaceae bacterium $\mathrm{WH} 2(85 \%)$, respectively (Table 3). Two unique bands, no. 4 and 5 found only in lysine and serine treatments were not successfully sequenced (Fig. 5c). In Fuchu soil, one unique band, no. 23 was present in lysine treatment (Fig. 5b), but it was not sequenced.

For the fungal community structure, DGGE banding profiles of the suppressive amino acid treatments (lysine and serine) belonged to the same cluster while the not suppressive treatments (the con+, tyrosine and valine) were in a different cluster in Nagoya soil (Fig. 7a). A similar trend was noted in Fuchu soil (Fig. 7b). In Iwate soil, DGGE pattern in the suppressive treatments (lysine and serine) and con+ were in the same cluster while the not suppressive treatments (tyrosine and valine) belonged to a different cluster (Fig. 7c).

\section{Canonical correspondence analysis}

Canonical correspondence analyses (CCA) of the microbial and soil parameters (pathogen and total bacterial population, soil respiration, dehydrogenase activity and soil $\mathrm{pH}$ ) and rhizoplane DGGE profiles in Nagoya and Fuchu soils were done (Fig. 8). In the ordination diagram, the population of the pathogen (7, 17 and 30-day) positively correlated with the disease index. Bands were dispersed but the unique bacterial communities that formed in lysine and serine treatments were negatively correlated to the disease index (30day) as inferred by their opposite position to the disease index in the diagram (Fig. 8a, 8b).

\section{Efficacy of lysine under greenhouse condition}

The addition of lysine at $1.0 \mathrm{mg} \mathrm{g}^{-1}$ to Fuchu soil reduced the TBW infection by up to $50 \%$ relative to cont+ with $100 \%$
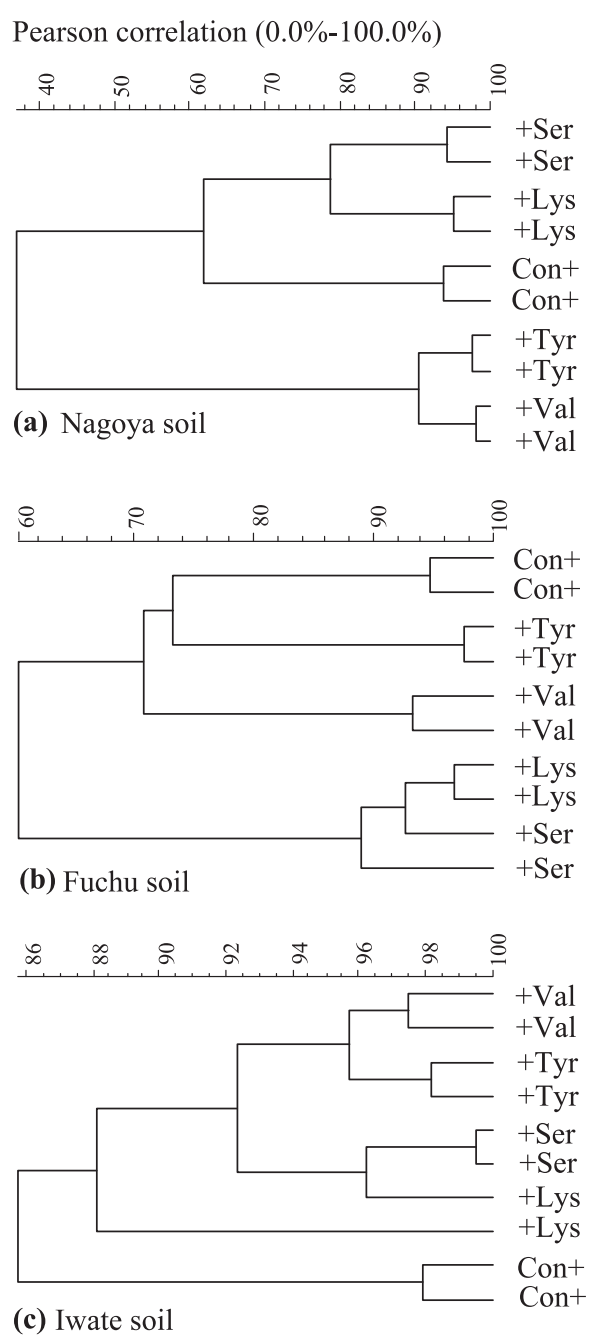

Fig. 7. Cluster analysis of DGGE patterns of rhizoplane fungal communities from different amino acid treatments in (a) Nagoya, (b) Fuchu and (c) Iwate soil. 


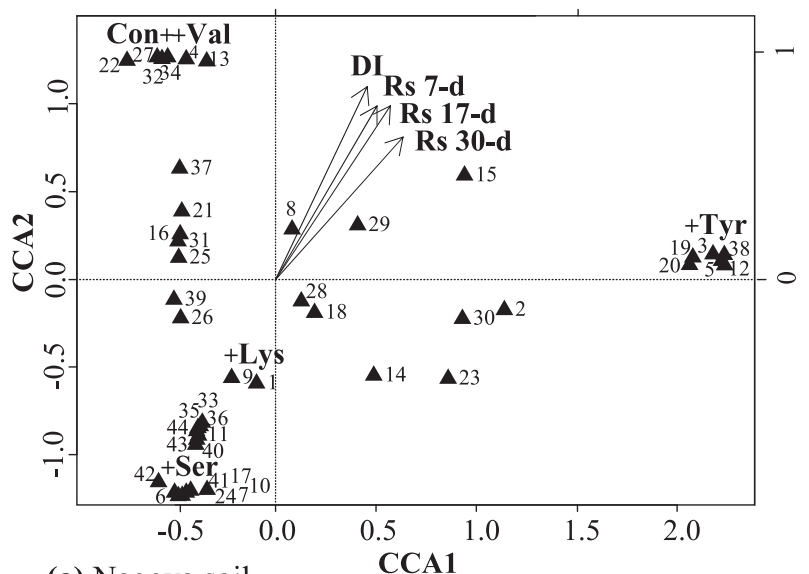

(a) Nagoya soil

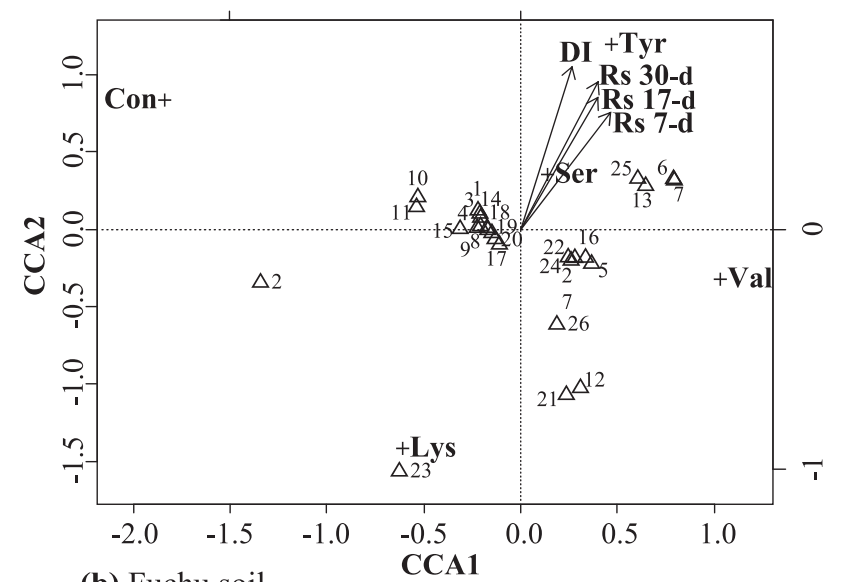

(b) Fuchu soil

Fig. 8. CCA ordination plot of bacterial communities associated with the rhizoplane of tomato grown in (a) Nagoya and (b) Fuchu soil added with different amino acids $\left(2.5 \mathrm{mg} \mathrm{g}^{-1}\right.$ soil) and different soil chemical and biological properties. Arrows represents DI and Rs population at different incubation period. Numbers with close and open triangles corresponds to DGGE band numbers in Nagoya and Fuchu soil in Fig. 5, respectively.

disease infection, 18 weeks after inoculation of the pathogen (Table 4). Lysine applied at $2.5 \mathrm{mg} \mathrm{g}^{-1}$ soil displayed a phytotoxic effect with $100 \%$ death of transplanted tomato plants. Wilted plants did not exhibit the characteristic bacterial oozing associated with TBW, hence they were not considered as TBW diseased plants. Tomato yield was comparable between the cont- and lysine at $1.0 \mathrm{mg} \mathrm{g}^{-1}$ soil but significantly higher than in con+. The population of the pathogen in the rhizoplane was highest in con $+\left(8.48 \log \mathrm{CFU} \mathrm{g} \mathrm{g}^{-1}\right.$ fresh root) and significantly $(P<0.001)$ lower in treatments applied with lysine at 1.0 and $2.5 \mathrm{mg} \mathrm{g}^{-1}$ soil with values of 7.10 and $7.02 \log \mathrm{CFU} \mathrm{g}^{-1}$ fresh root, respectively, 30-day after amino acid addition.

\section{Discussion}

We previously reported that a suppressive effect of lysine and serine against TBW in Nagoya and Iwate soil was correlated with higher microbial activity and decline of the pathogen in bulk soil (33). In the present study, reproducible suppressive effects of lysine and serine were observed in another Fuchu soil as well as in the Nagoya and Iwate soils. In addition, this study further supported that disease suppressiveness by the amino acids was most likely related with the rapid decline of the pathogen's population since the pathogen died more quickly in the lysine and serine treatments than in tyrosine and valine treatments in all the soils used in spite of the non-utilization of these four amino acids by the pathogen. The canonical correspondence analysis of the disease index, microbial and soil parameters (pathogen and total bacterial population, soil respiration, dehydrogenase activity and soil $\mathrm{pH}$ ) and rhizoplane DGGE profiles in Nagoya and Fuchu soils confirmed that the decline of the pathogen population after the addition of lysine was closely related with TBW suppression (Fig. 8).

The mechanisms by which lysine suppressed TBW were analyzed based on the different microbial parameters. Two types of disease suppression, general and specific, have been described (14). General suppression is due to an increase in the activity of microbial community as a whole that either competes for resources and/or produces antimicrobial substances that reduce survival and growth of the pathogen (14). In this case, disease suppression will correlate with general microbial activity as estimated by dehydrogenase and respiration. On the other hand, specific suppression results from an increase in populations of certain microorganisms that are antagonistic or induce systemic resistance in the host plant to specific pathogens (15). In this case, a correlation between disease suppression and microbial activity is not always seen.

Soil respiration was not highest in the lysine treatment and was significantly $(P<0.05)$ higher in the tyrosine treatment than lysine treatment in two soils (Fig. 3). In addition, dehydrogenase activity at 7 days after the addition of amino acids was not higher in the lysine treatment than tyrosine treatment, although it was higher in the lysine and serine treat-

Table 4. Effect of lysine addition on the disease index (DI) of tomato bacterial wilt and quality of tomato fruits after harvest in greenhouse experiment using Fuchu soil

\begin{tabular}{lccccc}
\hline \multicolumn{1}{c}{ Treatment } & Dl value* & $\begin{array}{c}\text { Height** } \\
(\mathrm{cm})\end{array}$ & $\begin{array}{c}\text { Yield } \\
\left(\mathrm{g} \mathrm{plant}^{-1}\right)\end{array}$ & $\begin{array}{c}\text { EC*** } \\
\left(\mathrm{mS} \mathrm{cm}^{-1}\right)\end{array}$ & $\begin{array}{c}\text { Sugar } \\
(\%)\end{array}$ \\
\hline Control- (No pathogen) & $0 \mathrm{c}$ & $138 \mathrm{~b}$ & $878 \mathrm{a}$ & 1.3 & 6.3 \\
Control+ (Pathogen alone) & $4 \mathrm{a}$ & all wilted & $140 \mathrm{~b}$ & 1.1 & 6.1 \\
+ Lysine (1.0 $\mathrm{mg} \mathrm{g}^{-1}$ soil) & $2 \mathrm{~b}$ & $199 \mathrm{a}$ & $1108 \mathrm{a}$ & 1.5 & 6.5 \\
\hline
\end{tabular}

* DI value; 1,1 to $25 \% ; 2,26$ to $50 \% ; 3,51$ to $75 \% ; 4,76$ to $100 \%$ infection.

** Plant height taken at 18 weeks after transplanting.

*** EC, electric conductivity.

Values with the same letter are not significantly different according to the protected Fisher's LSD test $(P=0.05)$. 
ments than valine and tyrosine treatments at 17 and 30 days after addition. The typical wilt symptoms were observed in tomato plants from 10 days after the addition of amino acids, suggesting that the microbial community in soil for 10 days after the addition of amino acids was most probably involved in the disease suppression by lysine. This may indicate that dehydrogenase activity was not always higher in the diseasesuppressive amino acids than non-suppressive ones, like soil respiration, when dehydrogenase activity at day 7 was focused on. This result contradicted with our previous paper in which higher TBW suppression was correlated with higher dehydrogenase activity (33). Our previous study tested a large number (12) of organic compounds including different kinds of amino acids and sugars (utilizable and/or unutilizable by the pathogen), which could have contributed to the negative correlation between dehydrogenase activity and disease suppression. These results implied that higher microbial activity appeared to be not correlated with the disease incidence. Hence, the mechanism of disease suppression by lysine might not only be related to higher microbial activity but involves other factors.

The contribution of lysine to induced systemic resistance in tomato plants was evaluated. The complete susceptibility of tomato plants grown in soil added with lysine and inoculated with the pathogen suggested little involvement of induced systemic resistance in TBW suppression by lysine, since validamycin A which was reported to induce systemic resistance in tomato plants (16) significantly suppressed TBW. Little contribution of induced resistance was further supported by the transplanting method and leaf cut method, although productions of pathogenesis-related proteins and salicylic acid, possible mediators in induced systemic resistance $(16,48)$, were not tested in this study.

SIR demonstrated that the addition of amino acids, especially lysine, made the soil more predominated by bacteria (Table 2). This result might indicate that bacteria increased with the addition of lysine are involved in the disease suppression. Total bacterial populations in non-rhizosphere soil, rhizosphere soil and rhizoplane were significantly higher in the lysine and serine treatments than in the valine and tyrosine treatments, further suggesting bacterial roles in the disease suppression by lysine and serine. This hypothesis was further supported by the DGGE patterns (Fig. 5), evidenced by a cluster analysis showing different clusters between disease-suppressive and non-suppressive amino acids (Fig. 6). In addition, the specific bacterial communities that developed in the lysine treatment were discernable in DGGE targeting the 16S rRNA gene in the tomato rhizoplane. For instance in Nagoya soil, 10 bands developed in the lysine treatment that were absent in the not-suppressive amino acids and 3 bands were unique only to the lysine treatment. CCA ordination revealed that the bands closely related to the lower disease index in the lysine treatment were 1 and 9 in Nagoya soil (Fig. 8a) and 23 in Fuchu soil (Fig. 8b), although these three bands were not successfully sequenced. The present study showed that the application of lysine or serine had stimulated unique bacteria (compared to tyrosine and valine) that were different depending on the kind of soil, and suggested that these unique bacteria might have contributed to the suppression of the bacterial pathogen and bacterial wilt disease.

The contribution of the fungal community to the suppression of TBW cannot be neglected from the present study since fungal profiles of the lysine and serine treatments belonged to the same cluster, different from that of the valine and tyrosine treatments (Fig. 7). This possibility should be further tested.

The addition of compounds unutilizable by the pathogen led to a decline of pathogen population due to competition by other microbes that were able to utilize the compounds (Okamura, Y., et al. 10 September 1999, Japan Patent Office). However, our study indicated that not all organic compounds unutilizable by the pathogen were suppressive, as exemplified by tyrosine and valine. The difference in the effects of unutilizable amino acids on TBW suppression was explained by the better survival of the bacterial pathogen in the not suppressive amino acids (tyrosine and valine), which corresponded with the increase in wilt incidence. However, since soil respiration was significantly higher in the tyrosine treatment than lysine treatment, lower decomposition would not be a reason for non-suppression of TBW by the amino acids. Results of DGGE profiles suggested that whether a specific community developed or not by the addition of amino acids could determine whether TBW was suppressed or not.

Enhanced suppression of soilborne bacterial plant diseases due to organic matter has been reported by several researchers. The decrease of $R$. solanacearum biovar 2 population by household compost addition reduced the incidence of potato wilt in microcosm experiments (37). DGGE profiles revealed an induced change in the structure of indigenous bacterial communities following addition of the compost with two major bands affiliated to Variovorax paradoxus and Aquaspirillium psychrophylum. The decline of $R$. solanacearum strain 22R6 was accompanied by an increase in total bacteria of soil applied with dried residues of selected cruciferous plants (31). The inhibitory effect was linked to the formation of certain bacterial communities in response to the application of the residues. Furthermore, the suppressiveness of compost against a variety of soilborne fungal diseases was correlated with biotic rather than abiotic factors (15). The modified microbial community composition effected by the addition of compost stimulated competition or antagonism among microbes that in turn inhibited the activity of the fungal pathogens $(6,10)$. The availability of free glucose enhanced the suppressive effect of Pseudomonas sp. against Escherichia coli O157:H7 ATCC43895 (40). Similarly, the improved efficacy of $B$. nodosa G5.2rif1 in combination with sucrose for the control of TBW was confirmed by Nion and Toyota (28). Disease suppression was attributed to the efficient utilization of sucrose and consequent increase in the population of the biocontrol agent, $B$. nodosa G5.2rif1. Similarly, lysine might have been efficiently utilized by naturallyoccurring biocontrol agents and increased their numbers in the soil, which subsequently increased its suppressiveness to pathogen survival and TBW incidence.

Results of the experiment conducted under greenhouse condition further verified the efficacy of lysine applied at 1.0 $\mathrm{mg} \mathrm{g}^{-1}$ to Fuchu soil against TBW. Consistent with the results from laboratory bioassays, greenhouse test of lysine's suppression of TBW was characterized by a reduction in dis- 
ease severity and inhibition of the pathogen's growth in the tomato rhizoplane. Several cases of soil borne disease suppression in organically amended soils were also connected to biotic rather than abiotic factors (10). This study implied that the addition of lysine for the control of TBW likely had created an environment favorable for the increase of bacterial populations including ones antagonistic to RsYU1Rif43. Our finding also conforms with Mazzola (27) who mentioned that the biocontrol of soilborne plant pathogens with the use of organic amendments is related to specific suppression with an increase in the population of specific or groups of microorganisms that might be antagonistic to the pathogens. Lysine addition also presents a great potential to be a part of the integrated soilborne disease management especially against TBW. However, the efficacy of lysine application under field condition still needs to be verified.

\section{Acknowledgements}

M. Posas would like to express her gratitude to the Ministry of Education, Science, Sports and Culture of Japan for her scholarship. Our sincere thanks also to K. Kawamura of Ajinomoto Healthy Supply Co., Inc. for kindly providing the lysine used in this study.

\section{References}

1. Abbasi, P.A., G. Lazarovits, and K.L. Conn. 2008. Enhancing biological control of soilborne plant disease by organic soil amendments, p. 319-344. In E. Ait Barka and C. Clément (ed.), Plant Microbe Interactions. Trivandrum, Kerala.

2. Aliye, N., C. Finisa, and Y. Hiskias. 2008. Evaluation of rhizosphere bacterial antagonists for their potential to bioprotect potato (Solanum tuberosum) against bacterial wilt (Ralstonia solanacearum). Biol. Control 47:282-288.

3. Arwiyanto, T., M. Goto, S. Tsuyumu, and Y. Takikawa. 1994 Biological control of bacterial wilt of tomato by an avirulent strain of Pseudomonas solanacearum isolated from Trelitzia reginae. Ann. Phytopathol. Soc. Jpn. 60:421-430.

4. Das, M., T.V. Royer, and L.G. Leff. 2007. Diversity of fungi, bacteria, and actinomycetes on leaves decomposing in a stream. Appl. Environ. Microbiol. 73:756-767.

5. Davis, R.F., P.A. Backman, R. Rodriguez-Kabana, and N. Kokalis-Burelle. 1992. Biological control of apple fruit diseases by Chaetomium globosum formulations containing cellulose. Biol. Control 2:118-123.

6. Diab, H.G., S. Hu, and D.M. Benson. 2003. Suppression in Rhizoctonia solani on impatiens by enhanced microbial activity in composted swine waste-amended potting mixes. Phytopathology 93:1115-1123.

7. Duffy, B.K., and G. Défago. 1997. Zinc improves biocontrol of Fusarium crown and root rot of tomato by Pseudomonas fluorescens and represses the production of pathogen metabolites inhibitory to bacterial antibiotic biosynthesis. Phytopathology 87:1250-1257.

8. Fujino, C., S. Wada, T. Konoike, K. Toyota, Y. Suga, and J. Ikeda. 2008. Effect of different organic amendments on the resistance and resilience of the organic matter decomposing ability of soil and the role of aggregated soil structure. Soil Sci. Plant Nutr. 54:534-542.

9. Fukui, R. 2003. Suppression of soilborne plant pathogens through community evolution of soil microorganisms. Microbes Environ. 18:1-9.

10. Garbeva, P., J.A. van Veen, and J.D. van Elsas. 2004. Assessment of the diversity, and antagonism towards Rhizoctonia solani AG3, of Pseudomonas species in soil from different agricultural regimes. FEMS Microbiol. Ecol. 47:51-64.

11. Gava, C.A.T., J.C. Pereira, M.C.P. Neves, and M.D.C. Fernandes. 2002. Selection of Streptomycetes isolates for the control of Ralstonia solanacearum in tomato plants. Pesq. Agropec. Bras. 37:1373-1380.

12. Haas, D., and G. Défago. 2005. Biological control of soil-borne pathogens by fluorescent pseudomonads. Nat. Rev. Microbiol. 3:307-
319.

13. Hayward, A.C. 1991. Biology and epidemiology of bacterial wilt caused by Pseudomonas solanacearum. Ann. Rev. Phytopathol. 29:65-87.

14. Hoitink, H.A.J., M.J. Boehm, and Y. Hadar. 1993. Mechanisms of suppression of soilborne plant pathogens in compost amended substrates, p. 601-621. In H.A.J. Hoitink, and H.M. Keener (ed.), Science and Engineering of Composting: Design, Environmental, Microbiological and Utilization Aspects. Renaissance Publications, Worthington.

15. Hoitink, H., and M. Boehm. 1999. Biocontrol within the context of soil microbial communities: a substrate-dependent phenomenon. Ann. Rev. Phytopathol. 37:427-446.

16. Ishikawa, R., K. Shirouzo, T. Nakashita, T. Teraoka, and T. Arie. 2007. Control efficacy of validamycin A against Fusarium wilt correlated with severity of phytotoxic necrosis formed on tomato tissues. J. Pestic. Sci. 32:83-88.

17. Islam, T.M.D., and K. Toyota. 2004. Suppression of bacterial wilt of tomato by Ralstonia solanacearum by incorporation of composts in soil and possible mechanisms. Microbes Environ. 19:53-60.

18. Janisiewicz, W.J., and B. Bors. 1995. Development of a microbial community of bacterial and yeast antagonists to control woundinvading postharvest pathogens of fruits. Appl. Environ. Microbiol. 61:3261-3267.

19. Kay, E., F. Bertolla, T.M. Vogel, and P. Simonet. 2002. Opportunistic colonization of Ralstonia solanacearum infected plants by Acinotebacter sp. and its natural competence development. Microb. Ecol. 43:291-297.

20. Kistner, T., G. Nitz, and W.H. Schnitzler. 2004. Adding olive mill waste water to hydroponic nutrient solutions: a potential agent against microbial diseases. Acta Hort. 659:315-321.

21. Kotsou, M., I. Mari, K. Lasaridi, I. Chatzipavlidis, C. Balis, and K. Adamantini. 2004. The effect of olive oil mill wastewater (OMW) on soil microbial communities and suppressiveness against Rhizoctonia solani. Appl. Soil Ecol. 26:113-121.

22. Lazarovits, G. 2001. Management of soil-borne plant pathogens with organic soil amendments: a disease control strategy salvaged from the past. Can. J. Plant Pathol. 23:1-7.

23. Lazarovits, G., K.L. Conn, P.A. Abbasi, and M. Tenuta. 2005. Understanding the mode of action of organic soil amendments provides the way for improved management of soilborne plant pathogens. Acta Hort. 698:215-225.

24. Lemessa, F., and W. Zeller. 2007. Screening rhizobacteria for biological control of Ralstonia solanacearum in Ethiopia. Biol. Control 42:336-344.

25. Lugtenberg, B.J.J., and L.C. Dekkers. 1999. What makes Pseudomonas bacteria rhizosphere competent? Environ. Microbiol. 1:9-13.

26. May, L.A., B. Smiley, and M.G. Schmidt. 2001. Comparative denaturing gradient gel electrophoresis of fungal communities associated with whole plant corn silage. Can. J. Microbiol. 47:829-841.

27. Mazzola, M. 2002. Mechanisms of natural soil suppressiveness to soilborne diseases. Antonie van Leeuwenhoek 81:557-564.

28. Nion, Y.A., and K. Toyota. 2008. Suppression of bacterial wilt and Fusarium wilt by Burkholderia nodosa strain isolated from Kalimantan soils, Indonesia. Microbes Environ. 23:134-141.

29. Nishijima, T., K. Toyota, and M. Mochizuki. 2005. Predominant culturable Bacillus species in Japanese arable soils and their potential as biocontrol agents. Microbes Environ. 20:61-68.

30. Notz, R., M. Maurhofer, H. Dubach, D. Haas, and G. Defago. 2002. Fusaric acid-producing strains of Fusarium oxysporum alter 2,4diacetylphloroglucinol biosynthetic gene expression in Pseudomonas fluorescens CHA0 in vitro and rhizosphere of wheat. Appl. Environ. Microbiol. 68:2229-2235.

31. Olivier, A.R., Y. Uda, S.W. Bang, H. Honjo, M. Fukami, and R. Fukui. 2006. Dried residues of specific cruciferous plants incorporated into soil can suppress the growth of Ralstonia solanacearum, independently of glucosinolate content of the residues. Microbes Environ. 21:216-226.

32. Oros-Sichler, M., N.C.M. Gomes, G. Neuber, and K. Smalla. 2006. A new seminested PCR protocol to amplify large 18S rRNA gene fragments for PCR-DGGE analysis of soil fungal communities. J. Microbiol. Methods 65:63-75.

33. Posas, M.B., K. Toyota, and T.M.D. Islam. 2007. Inhibition of bacterial wilt of tomato caused by Ralstonia solanacearum by sugars 
and amino acids. Microbes Environ. 22:290-296.

34. Saddler, G.S. 2005. Management of bacterial wilt disease, p. $121-$ 132. In C. Allen, P. Prior, and A.C. Hayward (ed.), Bacterial Wilt Disease and the Ralstonia solanacearum Species Complex. APS Press, St. Paul.

35. Salles, J.F., J.A. van Veen, and J.D. van Elsas. 2004. Multivariate analyses of Burkholderia species in soil: effect of crop and land use history. Appl. Environ. Microbiol. 70:4012-4020.

36. Sato, E., Y.Y. Min, T. Shirakashi, S. Wada, and K. Toyota. 2007. Detection of root-lesion nematode, Pratylenchus penetrans (Cobb), in a nematode community using real-time PCR. Jpn. J. Nematol. 37:8792.

37. Schonfeld, J., A. Gelsomino, L.S. Overbeek, A. van Gorissen, K. Smalla, and J.D. van Elsas. 2003. Effects of compost addition and simulated solarization on the fate of Ralstonia solanacearum biovar 2 and indigenous bacteria in soil. FEMS Microbiol. Ecol. 43:63-74.

38. Shrestha, A., K. Toyota, M. Okazaki, Y. Suga, M.A. Quevedo, A.B. Loreto, and A.L. Mariscal. 2007. Enhancement of nitrogen-fixing activity of Enterobacteriaceae strains isolated from sago palm (Metroxylon sagu) by microbial interaction with non-nitrogen fixers. Microbes Environ. 22:59-70.

39. Simons, M., H.P. Permentier, L.A. de Weger, C.A. Wijffelman, and B.J.J. Lugtenberg. 1997. Amino acid synthesis is necessary for tomato root colonization by Pseudomonas fluorescens strain WCS365. Mol. Plant-Microbe Interact. 10:102-106.

40. Sofos, J.N., and J. Samelis. 2002. Role of glucose in enhancing the temperature-dependent growth inhibition of Escherichia coli O157:H7 ATCC43895 by Pseudomonas sp. Appl. Environ. Microbiol. 68:2600-2604

41. Tabatabai, M.A. 1994. Soil enzymes, p. 775-833. In R.W. Weaver, S. Angle, and P. Bottomley (ed.), Methods of Soil Analysis: Part 2. Microbiological and Biochemical Properties. Soil Science Society of America, Madison.
42. Tchelet, R., R. Meckenstock, P. Steinle, and J.R. van der Meer. 1999. Population dynamics of an introduced bacterium degrading chlorinated benezenes in a soil column and in sewage sludge. Biodegradation 10:113-125.

43. Ter Braak, C.J.F. 1987. The analysis of vegetation-environment relationships by canonical correspondence analysis. Vegetation 69:69-77.

44. Toyota, K., and M. Kimura. 1996. Growth of the bacterial wilt pathogen Pseudomonas solanacearum introduced into soil colonized by individual soil bacteria. Soil Biol. Biochem. 28:1489-1494.

45. Toyota, K., and S. Kuninaga. 2006. Comparison of soil microbial community between soils amended with or without farmyard manure. Appl. Soil Ecol. 33:39-48.

46. Wada, S., and K. Toyota. 2007. Repeated applications of farmyard manure enhance the resistance and resilience of soil biological functions against soil disinfection. Biol. Fertil. Soils 43:349-356.

47. Weller, D.M. 1988. Biological control of soil borne plant pathogens in the rhizosphere with bacteria. Ann. Rev. Phytopathol. 26:379-407.

48. Vallad, G.E., and R.M. Goodman. 2004. Review and interpretation: systemic acquired resistance and induced systemic resistance in conventional agriculture. Crop Sci. 44:1920-1934.

49. Van Overbeek, L.S., M. Cassidy, J. Kozdroj, J.T. Trevors, and J.D. van Elsas. 2002. A polyphasic approach for studying the interaction between Ralstonia solanacearum and potential control agents in the tomato phytosphere. J. Microbiol. Methods 48:69-86.

50. Yamada, M., and M. Ogiso. 1997. Control of soil-borne diseases using antagonistic microorganisms. IV. Study on the available substrates for antagonistic bacterial strains to control Fusarium wilt of tomatoes. Res. Bull. Aichi-Ken Agric. Res. Cent. 29:141-144. 